\title{
Correlations Between Fish Assemblage Structure and Environmental Variables of Taruwa Pond in Nawalparasi District, Province No. 4, Nepal
}

\author{
KESHI CHAUDHARY ${ }^{1} \&$ JASH HANG LIMBU*2 \\ ${ }^{1}$ Shree Tribhuvan Bal Secondary School, Kawasoti-17, Dhoki, Nawalparasi, Nepal; ${ }^{2}$ Nature Conservation and \\ Health Care Council, Biratnagar, Nepal \\ *Corresponding author: limbujash@gmail.com \\ Received: 06 February 2020 \\ Accepted: 13 October 2020 \\ Published: 30 June 2021
}

\begin{abstract}
The correlations between fisheries diversity and environmental variables of Nepal's Pond are poorly understood. This study aims to investigate temporal variation of fish assemblage at Taruwa Pond in Nawalparasi district, Province no. 4, Nepal from October 2018 to April 2019. For the fish agglomeration, cast net of $4 \mathrm{~kg}$ in weight and $3.80 \mathrm{~m}$ in length and $22.5 \mathrm{~m}$ breadth with $12 \mathrm{~mm}$ mesh size was used. In total, 579 individuals representing 16 fish species, 10 families, and 12 genera were recorded. According to similarity percentage analysis, the most contributory species were Puntius ticto (27.92\%) followed by Danio devario (12.06\%), Puntius terio (9.76\%), Badis badis (7.31\%), Lepidocephalichthys guntea (5.57\%) and Puntius sophore (5.57\%). Analysis of similarity suggested that fish community structure was significantly different in temporal variation $(R=0.321, p<0.01)$. Based on the cluster analysis, fish assemblages were isolated into two distinct groups at Bray-curtis similarity. The Canonical Correspondence Analysis distinctly indicated that the water parameters of dissolved oxygen, carbon-dioxide, depth, and water temperature play an important role in influencing the fish assemblage structure of Taruwa Pond.
\end{abstract}

Keywords: Fish diversity, lake, pond, temporal, wetland

Copyright: This is an open access article distributed under the terms of the CC-BY-NC-SA (Creative Commons Attribution-NonCommercial-ShareAlike 4.0 International License) which permits unrestricted use, distribution, and reproduction in any medium, for non-commercial purposes, provided the original work of the author(s) is properly cited.

\section{INTRODUCTION}

Fish community structure surrounded by oxbow lakes, species richness, diversity, and evenness was eminent to fasten together oxbow lake (Winemiller et al., 2005). Similarly, oxbow lakes that are connected to the river have more species than lakes that have seceded from the river (Galat et al., 1998; Petry et al., 2003; Miranda, 2005; Miranda et al., 2014). The state of the lakes seems to be the serious factor affecting variety. It is broadly accepted that the fluctuation of environmental variables plays an imperative role in the organization of fish community structure (Tejirina et al., 1998; Amarasinghe \& Welcomme, 2002). Nevertheless, the important factors to decide species composition vary between water bodies, extending from natural environment, like lake structure and water chemistry (Zhao et al., 2006; Cheng et al., 2010). Even though there could be limnological distinctive effect on fish species richness in mild lakes, part of the surface area and altitude of the system have eminent predictive ability (Zhao et al., 2006). The temperature and dissolved oxygen (DO) concentration persuade the distribution, abundance and migration of aquatic organisms (Alhassan, 2013). The two key environmental variables such as the macrophyte complex and water depth play a crucial role in the spatial and seasonal variations of the fish assemblage structure in shallow lakes (Ye, 2007).

The present study analysed relationships among temporally varying fisheries diversity and environmental variables of one of the unexplored ponds, Taruwa pond of Nawalparsi district, to fill the gap of the information and hence dilate the fish diversity profile of Nepal. We assumed that fish abundance in the Taruwa pond would be greater during the annual dry season when aquatic habitats are reduced. We also assumed that fish assemblage structure would vary between seasonal variation defined by environmental variables such as water depth, water temperature, DO and free carbondioxide $\left(\mathrm{CO}_{2}\right)$. 


\section{MATERIALS AND METHODS}

\section{Study Area}

Taruwa Pond is a natural pond which is located in Kawasoti Municipality-7, Nawalparasi district (Figure 1). It is about $1.5 \mathrm{~km}$ south of Kawasoti, Mahendra highway at geographical coordinates a $27^{\circ} 37^{\prime} 58^{\prime \prime} \mathrm{N}$ and $84^{\circ} 07^{\prime} 51^{\prime \prime} \mathrm{E}$ and occupies an area of 1.8975 ha and its average depth is about 0.97 meter. The pond area is located at the altitude of $161.5 \mathrm{~m}$ (530 feet). Aquatic vegetation occurs in middle part and the littoral region and a tropical forest occupies northern part and human settlement surrounded southern part of its borders. The pond is divided into two portions (upper and lower) for the irrigation of agriculture land of approximately five villages.

\section{Fish Sampling and Preservation Techniques}

Fishes were collected from Taruwa Pond in the morning (9:00 am to 11:00 am) once every three months for seven months covering three seasons (autumn, winter and spring) starting from October (autumn) 2018 to April (spring) 2019.
Local fishermen were hired for fish sampling. From sampling site, fish samples were collected by using cast net. The cast net used for fish captured was $4 \mathrm{~kg}$ in weight and $3.80 \mathrm{~m}$ in length and 22.5 $\mathrm{m}$ breadth with $12 \mathrm{~mm}$ mesh size. The cast net was operated for 2 hours at sites (catch effort 15 times installation of cast net in pond for fishing in every three sampling months) in the morning. The number of fish species in the samples and the number of individuals in each species were counted and the collected specimens were preserved in $10 \%$ formaldehyde solution in labelled plastic jars and brought to Central Department of Zoology (Tribhuvan University, Institute of Science and Technology, Kirtipur, Kathmandu, Nepal) laboratory for further identification.

\section{Identification of Specimens and Deposition}

The collected fish specimens were identified using standard taxonomic references (Talwar \& Jhingran, 1991; Jayaram, 2010) and collected specimens at the field survey were deposited in the laboratory of the Central Department of Zoology, Trubbuwan University.

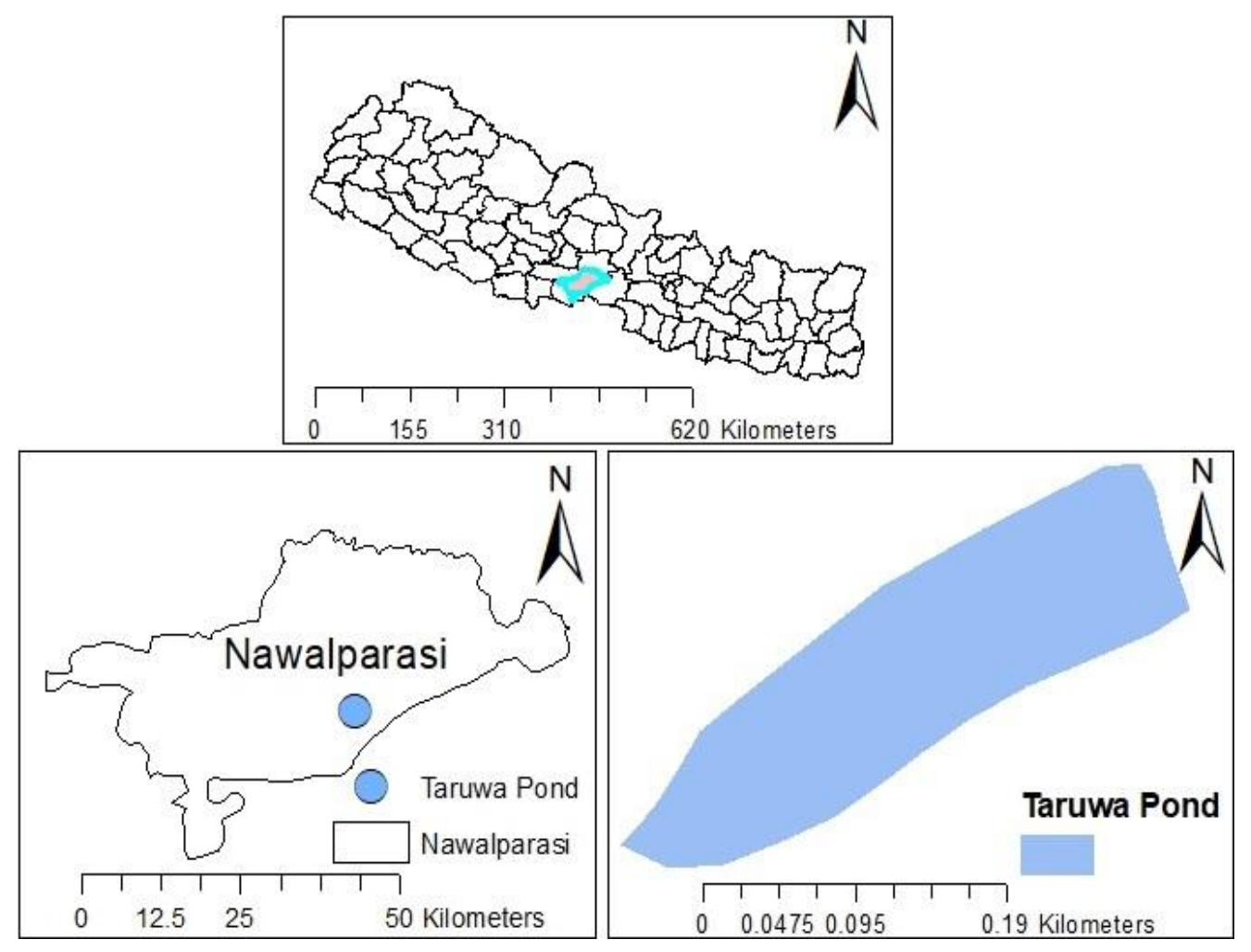

Figure 1. Map of study area showing Taruwa Pond 


\section{Analysis of Environmental Variables}

The environmental parameters were determined following standard methods of APHA (1976), Adoni (1985), and Trivedy and Goel (1989). Water samples of Taruwa Pond were collected during morning time (9:00 am to 10:00 am) and analysed once every three months during each field visit. The environmental variables measured during the field visit include water temperature, DO, water depth, turbidity and free carbon dioxide. Water temperature $\left({ }^{\circ} \mathrm{C}\right)$ was measured using a digital thermometer by putting it down in the water at a depth of one feet within one minute and the obtained value was recorded. Dissolved oxygen was measured in-situ using a Winkler titra-metric method in each season. The depth was measured by using nylon rope with weight and a measuring tape was used to record the depth in centimeter $(\mathrm{cm})$. To measure the turbidity, water samples were collected in a bottle and measured directly with turbidity meter (Turb Delagua).

\section{Data Analysis}

The Shannon-Weiner diversity index (Shannon \& Weaver, 1963) was calculated using following formula:

$\mathrm{H}=\sum_{i=1}^{S} P i * \log P i$

Where $\mathrm{S}$ is the total number of species and $P i$ is the relative cover of $i_{t h}$ of species.

Margalef richness index (d) (Margalef, 1968) was used to measure species richness by using following formula:

$d=(\mathrm{S} / 1)=\log (N)$

Where $\mathrm{S}$ is the total species and $N$ is total individual.

Evenness index (Pieleu, 1966) was determined by the following equation:

$\mathrm{E}=\mathrm{H}^{\prime} / \log \mathrm{S}$

Where, $\mathrm{H}^{\prime}=$ Shannon- Weiner's diversity index. $\mathrm{S}$ $=$ Total number of species in the sample.

To know the correlation between fish assemblage and environmental variables, first, we performed Detrended Correspondence Analysis (DCA) to determine whether the Redundancy Analysis
(RDA) or Canonical Correspondence Analysis (CCA) could be the most suitable paradigm to narrate the consortium between fish species and environmental parameters. The axis length and Eigen value acquired from DCA proposed that the linear replica of CCA was more relevant. Therefore, a direct multivariate ordination method (Ter Braak \& Prentice, 1988), based on a linear response of species to environmental gradients Gauch (1982) was applied using library "vegan" in $\mathrm{R}$ (Oksanen et al., 2019). One-way analysis of similarity (ANOSIM) (Clarke, 1993) was used to conclude the importance of temporal variation of fish community structure. Moreover, fish species were scrutinized into dissimilar assemblage clusters based upon opulence of each fish species by utilizing pvclust package in $\mathrm{R}$ (Suzuki \& Shimodaira, 2015). Similarity percentage analysis (SIMPER) (Clarke, 1993) was executed to observe the percentage of similarity in temporal scale.

\section{RESULTS AND DISCUSSION}

A total of 16 fish species were collected during the study period which included 10 families and 12 genera (Table 1). The five fish species belonged to the family Cyprinidae were found as dominant family and the lowest number of fish species belonged to families Belonidae, Bagridae and Channidae with single fish species, while each of the other four families (Cobitidae, Mastacembelidae, Nandidae and Osphronemidae) were represented by two species. The findings of the present study were congruous with the findings of Limbu et al. (2016), Subba et al. (2017), Prasad and Limbu (2017), Limbu et al. (2018), Limbu and Gupta (2019), Limbu and GC (2019), Limbu et al. (2019), Limbu et al. (2019), Limbu and Prasad (2020), Limbu et al. (2020) and Limbu et al. (2021). Out of total fish catch, 386 fishes belonged to family Cyprinidae with the highest frequency $(66.67 \%)$. The fish species belonging to families Belonidae, Bagridae and Channidae were represented with different fish catch frequency of $2.94 \%, 2.59 \%$ and $4.32 \%$, respectively. During study period, family Mastacembelidae comprised the least number of fish catch (five individuals). The dominant fish species of Taruwa Pond were Puntius terio, P. ticto, P. sophore, Danio devario, Esomus danricus, Lepidocephalichthys guntea, Acanthocobitis botia, Channa punctata and Badis badis. The most abundant fish species of Taruwa pond was $P$. ticto with highest fish catch and lowest fish catch was of Mastacembelus armatus with single individual was recorded. 
Table 1. Fishes of Taruwa Pond

\begin{tabular}{|c|c|c|c|c|c|c|c|}
\hline \multirow[t]{2}{*}{ Family } & \multirow[t]{2}{*}{ Name of fish } & \multirow[t]{2}{*}{ Code } & \multicolumn{3}{|c|}{ Seasons } & \multirow[t]{2}{*}{ Total } & \multirow{2}{*}{$\begin{array}{l}\text { Percentages of } \\
\text { total } \\
\text { individuals } \\
\text { caught }(\%)\end{array}$} \\
\hline & & & Autumn & Winter & Spring & & \\
\hline Cyprinidae & $\begin{array}{c}\text { Puntius terio } \\
\text { (Hamilton, 1822) }\end{array}$ & $\mathrm{C} 1$ & 34 & 12 & 14 & 60 & 10.36 \\
\hline Cyprinidae & $\begin{array}{c}\text { Puntius ticto } \\
\text { (Hamilton, 1822) }\end{array}$ & $\mathrm{C} 2$ & 128 & 70 & 55 & 253 & 43.70 \\
\hline Cyprinidae & $\begin{array}{l}\text { Puntius sophore } \\
\text { (Hamilton, 1822) }\end{array}$ & $\mathrm{C} 3$ & 15 & 2 & 5 & 22 & 3.80 \\
\hline Cyprinidae & $\begin{array}{c}\text { Danio devario } \\
\text { (Hamilton, 1822) }\end{array}$ & $\mathrm{C} 4$ & 30 & 9 & - & 39 & 6.74 \\
\hline Cyprinidae & $\begin{array}{l}\text { Esomus danricus } \\
\text { (Hamilton, 1822) }\end{array}$ & $\mathrm{C} 5$ & 7 & - & 5 & 12 & 2.07 \\
\hline Cobitidae & $\begin{array}{c}\text { Lepidocephalichthys } \\
\text { guntea (Hamilton, } \\
1822 \text { ) }\end{array}$ & C6 & 23 & 11 & 10 & 44 & 7.60 \\
\hline Nemacheilidae & $\begin{array}{c}\text { Acanthocobitis botia } \\
\text { (Hamilton, 1822) }\end{array}$ & $\mathrm{C} 7$ & 11 & 12 & 3 & 26 & 4.49 \\
\hline Belonidae & $\begin{array}{c}\text { Xenentodon cancila } \\
\text { (Hamilton, 1822) }\end{array}$ & $\mathrm{C} 8$ & 11 & 5 & 1 & 17 & 2.94 \\
\hline Bagridae & $\begin{array}{c}\text { Mystus tengara } \\
\text { (Hamilton-Buchanan, } \\
1822 \text { ) }\end{array}$ & C9 & 9 & 3 & 3 & 15 & 2.59 \\
\hline Mastacembelidae & $\begin{array}{c}\text { Macrognathus } \\
\text { pancalus (Bloch, } \\
1801)\end{array}$ & $\mathrm{C} 10$ & 3 & 1 & - & 4 & 0.69 \\
\hline Mastacembelidae & $\begin{array}{c}\text { Mastacembelus } \\
\text { armatus (Lacepede, } \\
1800)\end{array}$ & $\mathrm{C} 11$ & 1 & - & - & 1 & 0.17 \\
\hline Channidae & $\begin{array}{l}\text { Channa punctata } \\
\text { (Bloch, 1793) }\end{array}$ & $\mathrm{C} 12$ & 9 & 8 & 8 & 25 & 4.32 \\
\hline Nandidae & $\begin{array}{c}\text { Nandus nandus } \\
\text { (Hamilton-Buchanan, } \\
\text { 1822) }\end{array}$ & $\mathrm{C} 13$ & 4 & 2 & - & 6 & 1.04 \\
\hline Badidae & $\begin{array}{c}\text { Badis badis } \\
\text { (Hamilton-Buchanan, } \\
\text { 1822) }\end{array}$ & $\mathrm{C} 14$ & 12 & 20 & 8 & 40 & 6.90 \\
\hline Osphronemidae & $\begin{array}{c}\text { Colisa lalia } \\
(\text { Schneider, 1801) }\end{array}$ & $\mathrm{C} 15$ & - & - & 7 & 7 & 1.21 \\
\hline \multirow[t]{2}{*}{ Osphronemidae } & $\begin{array}{c}\text { Colisa fasciata } \\
\text { (Schneider, 1801) }\end{array}$ & C16 & - & - & 8 & 8 & 1.38 \\
\hline & Total & & 297 & 155 & 127 & 579 & 100 \\
\hline
\end{tabular}




\section{Diversity Status}

The value of Shannon-Weiner diversity index was found to be lowest during winter season (Figure 2). This would be due to the weatherbeaten and feed consequence. The fish can conceal themselves under natural shield in pools in the month of January because of utmost drop of temperature in winter season and hence possibility of fish catch by cast/drag net are impoverished. Species richness diversified in seasons but there was no particular seasonal tendency. The differences in species richness and diversity in relation to different sampling periods and seasons have been noticed in several studies (Ornellas \& Coutinho, 1998; Pires et al., 1999; Reichard et al., 2002).

\section{Fish Assemblages}

One-way ANOSIM with replication testing for temporal variation in fish assemblages suggested that there was a significant difference in temporal variation $(R=0.321, p<0.01)$. The SIMPER manifested that the average dissimilarity of species in three (autumn, winter and spring) seasons was $39.64 \%$. The most contributory species was $P$. ticto $(27.92 \%)$ followed by $D$. devario $(12.06 \%), P$. terio (9.76\%), B. badis $(7.31 \%)$, L. guntea $(5.57 \%)$ and $P$. sophore $(5.57 \%)$, respectively.

Hierarchial clustered dendrogram of fish species from the Taruwa Pond, black and bold coloured number represents the cluster number, red represents probability of Automatic Unbiased (AU) value and blue colour number represents Bootstap Probability (BP) value, where AU value $\geq 95$ represents significant cluster (Figure 3). According to cluster analysis, fish assemblage structure of Taruwa Pond was grouped into two major cluster groups with 12 sub-cluster groups. On the left side of the plot, cluster number 14 was further grouped into two major sub-cluster groups and all the sub-cluster showed significant distance correlation to each other. On the contrary, one of the major cluster number 13 showed significant distance correlation with the cluster groups 12,8 , 6,3 and 9 .

\section{Relationship Between Species and Environment}

The CCA ordination described significant relationship (Monte Carlo permutation tests, $\mathrm{n}=$ 9999, $p<0.05$ ) between fish species and variables based on the data matrix. The first and second axis, calculating for $67.44 \%$ and $18.91 \%$ respectively for the variation of data, was used in the elucidation of the results. Fish species of $P$. sophore (C3), E. danricus (C5), Macrognathus pancalus (C10), C. punctate (C12), Colisa lalia (C15) and C. fasciata (C16) were positively related to DO and turbidity but negatively related to water depth and free $\mathrm{CO}_{2}$. The water temperature was positively related to Xenentodon

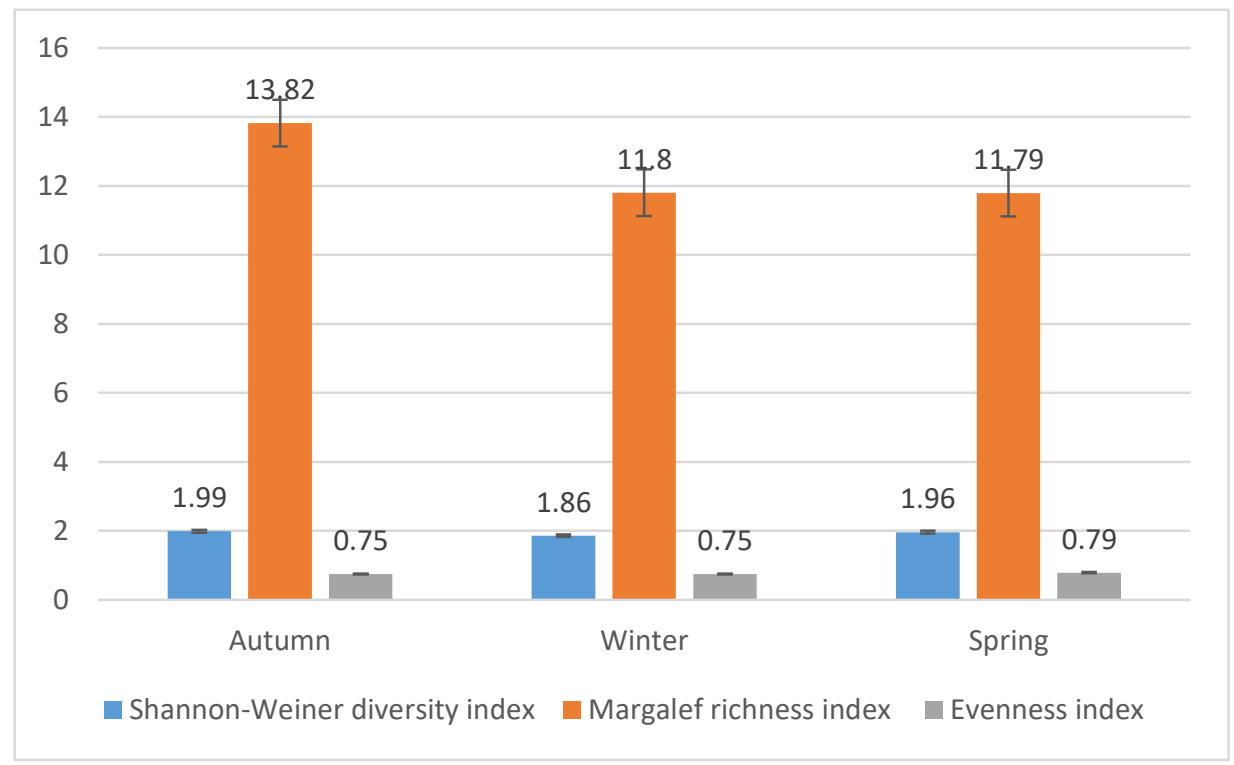

Figure 2. Season wise diversity index, species richness and evenness index 


\section{Cluster dendrogram with p-values (\%)}

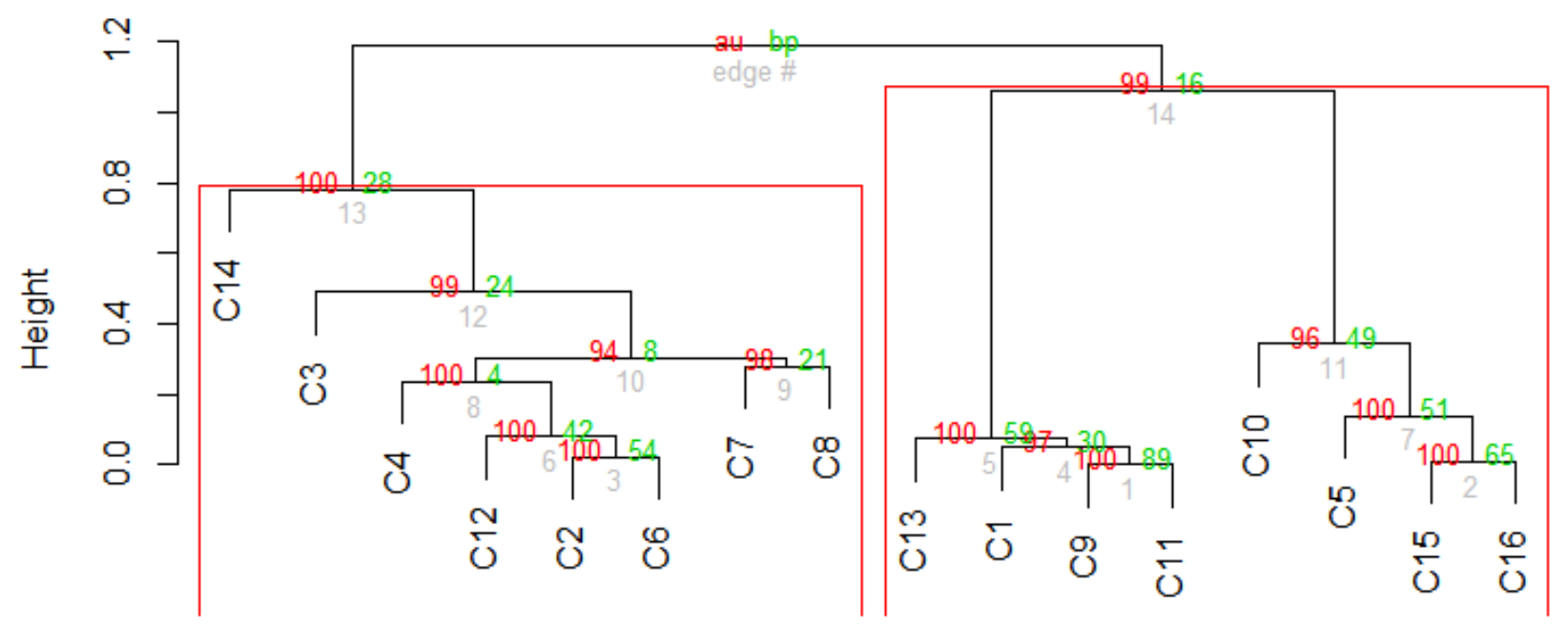

\section{Distance: correlation Cluster method: average}

Figure 3. Dendrogram of cluster analysis comparing fish species on the basis of fish assemblage (for species code, see Table 1). C1-C16 represent fish species, numbers in red represent probability of au value, numbers in green represent bootstrap probability value and numbers in grey represent clusters

cancila (C8) species and negatively related to $P$. terio (C1), Mystus tengara (C9), M. armatus (C11) and Nandus nandus (C13). Fish species of P. ticto (C2), D. devario (C4), L. guntea (C6), A. botia (C7) and B. badis (C14) were positively related to water depth and free $\mathrm{CO}_{2}$ but negatively related to turbidity and DO. The CCA distinctly indicated that the environmental variables of $\mathrm{DO}, \mathrm{CO}_{2}$, depth, and water temperature play a pivotal role to shape the fish assemblage structure of Taruwa Pond (Figure 4).

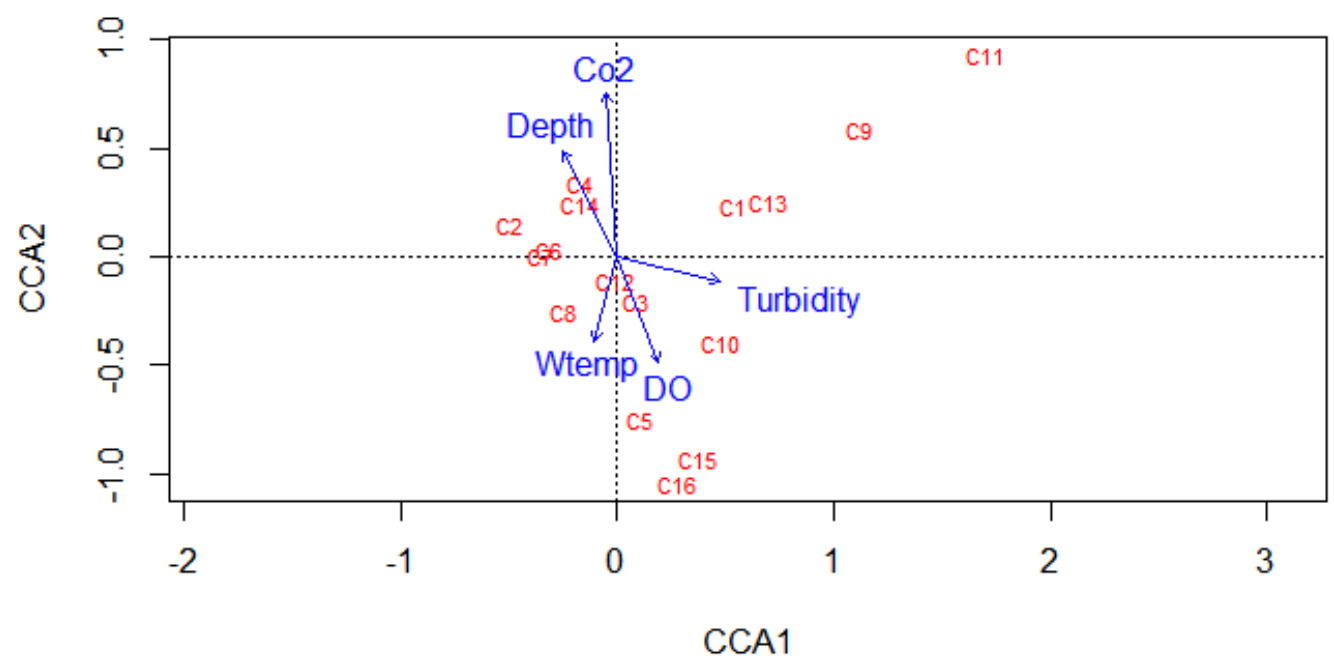

Figure 4. Canonical Correspondence Analysis (CCA) ordination of fish assemblages and environmental variables of Taruwa Pond (for species code, see Table 1). C1-C16 represent fish species 


\section{CONCLUSION}

In this study, 16 fish species were examined, among which are $P$. ticto followed by $D$. devario, $P$. terio, B. badis, L. guntea and $P$. sophore were the major contributory species, each contributed to more than $1 \%$ of the total composition. The CCA revealed that the water parameters of $\mathrm{DO}, \mathrm{CO}_{2}$, depth, and water temperature have a significant impact on the fish assemblage structure of Taruwa Pond.

\section{ACKNOWLEDGEMENTS}

We would like to express our sincere gratitude to Prof. Dr. Tej Bahadur Thapa, Head of Central Department of Zoology, Tribhuvan University for his kind suggestions, encouragement and academic support. We would like to convey our appreciation to Mr. Ganesh Mahato and Santa Bahadur Thapa, fishermen of the study area who assisted us with the fish catching and fishing technique. Our special thanks goes to Mr. Ram Narayan Khanal, Officer of Kawasoti Drinking Water and Sanitation Consumer Corporation and Mr. Nabin Pathak, Coordinator of Madhyabindu Multiple Campus, Kawasoti, Nawalparasi, for their co-operation during the analysis of water parameters.

\section{REFERENCES}

Adoni, A.D. (1985). Work book on limnology. Department of Environment, Government of India, Sagar, India, Pratibha Publication.

Alhassan, E.H. (2013). Hydro-biology and fish production of the Black Volta near the Bui Dam during the pre- and post-impoundment periods. (PhD Dissertation), University of Ghana, Legon.

Amarasinghe, U.S. \& Welcomme, R.L. (2002). An analysis of fish species richness in natural lakes. Environmental Biology of Fishes, 65: 327-339.

APHA, 1976. Standard methods for the examination of water and waste water, including Bottom sediments and sludge, $14^{\text {th }}$ ed., New York, USA.

Cheng, L., Lek, S., Loot, G., Ang, S.A. \& Li, Z. (2010). Variations of fish composition and diversity related to environmental variables in shallow lakes in the Yangtze River basin. Aquatic Living Resources, 23: 417-426.

Clarke, K.R. (1993). Non parametric multivariate analyses of changes in community structure.
Australian Journal of Ecology, 18: 117-143.

Galat, D.L., Fredrickson, L.H., Humburg, D.D., Bataille, K.J., Bodie, J.R. \& Dohrenwend, J. (1998). Flooding to restore connectivity of regulated, largeriver wetlands. Bio Science, 48: 721-733.

Gauch, H.G.J. (1982). Multivariate analysis in community ecology. Cambridge, UK, Cambridge University Press.

Jayaram, K.C. (2010). The freshwater fishes of Indian region. Delhi, India, Narendra Publishing House.

Limbu, J.H., Acharya, G.S \& Shrestha, OM. (2016). A brief report on ichthyofaunal diversity of Dewmai Khola of Ilam district, Nepal. Journal of Natural History Museum, 30: 312-317.

Limbu, J.H. \& Gupta, S. (2019). Fish diversity of Damak and lower Terai region of Ratuwa River of Jhapa district, Nepal. International Journal of Fauna and Biological Studies, 6(1): 1-4.

Limbu, J.H. \& Prasad, A. (2020). Environmental variables and fisheries diversity of the Nuwa River, Panchthar, Nepal. Scientific World, 13: 69-74.

Limbu, J.H. \& Punam, G.C. (2020). Spatio-temporal variation of fish assemblages in Babai River of Dang district, Province No. 5, Nepal. Our Nature, 17(1): 14-25.

Limbu, J.H., Gurung. J.K., Subba. S., Khadka. N., Adhikari, A. \& Baniya, C.B. (2021). An impact assessment of Betani irrigation dam on fish diversity of Damak municipality, Jhapa, Nepal. Egyptian Journal of Aquatic Biology and Fisheries, 25(2): 163-175.

Limbu, J.H., Baniya, C.B. \& Prasad, A. (2019). Spatiotemporal variation of fish assemblages in Ratuwa River, Ilam, Nepal. Journal of Ecology \& Natural Resources, 3(3): 1-11.

Limbu, J.H., Bhurtel, B., Adhikari, A., Punam, G.C., Maharjan, M. \& Sunuwar, S. (2020). Fish community structure and environmental correlates in Nepal's Andhi Khola. Borneo Journal of Resource Science and Technology, 10(2): 85-92. DOI: https://doi.org/10.33736/bjrst.2510.2020

Limbu, J.H., Chapagain, N., Gupta, S. \& Sunuwar, S. (2019). Review on fish diversity of eastern Nepal. International Journal of Fisheries and Aquatic Studies, 7(3): 177-181.

Limbu, J.H., Shrestha, O.H. \& Prasad, A. (2018). Ichthyofaunal diversity of Bakraha River of Morang 
district, Nepal. International Journal of Fisheries and Aquatic Studies, 6(5): 267- 271.

Margalef, R. (1968). Perspectives in ecological theory. Chicago, USA, Chicago University Press.

Miranda, L.E. (2005). Fish assemblages in oxbow lakes relative to connectivity with the Mississippi River. Transactions of American Fish Society, 134: 14801489.

Miranda, L.E., Andrews, C.S. \& Kroger, R. (2014) Connectedness of land use, nutrients, primary production, and fish assemblages in oxbow lakes. Aquatic Science, 76: 41-50.

Oksanen, J., Blanchet, F.G., Kindt, R., Legendre, P. \& Minchin, P.R., (2019). Vegan: Community ecology package. $\mathrm{R}$ package version 2: 3-1.

Ornellas, A.B. \& Coutinho, R. (1998). Spatial and temporal patterns of distribution and abundance of a tropical fish assemblage in a seasonal Sargassum bed, Cabo Frio Island, Brazil. Journal of Fish Biology, 53: 198-208.

Petry, A.C., Agostinho, A.A. \& Gomes, L.C. (2003). Fish assemblages of tropical floodplain lagoons: Exploring the role of connectivity in a dry year. Neotropical Ichthyology, 1: 111-119.

Pires, A.M., Cowx, I.G. \& Coelho, M.M. (1999). Seasonal changes in fish community structure of intermittent streams in the middle reaches of the Guadiana basin. Portugal Journal of Fish Biology, 54: 235-249.

Prasad, A. \& Limbu, J.H. (2017). Ichthyofaunal diversity of Phewa Khola of Ilam district, Nepal. Recent Life Sc. Mirror. An International Biannual Journal of Life Science; 6(1-2): 1-8.

Reichard, M., Jurajda, P. \& Ondrackova, M. (2002).
Interannual variability in seasonal dynamics and species composition of drifting young-of-the-year fishes in two European lowland rivers. Journal of Fish Biology, 60: 87-101.

Suzuki, R. \& Shimodaira, H. (2019). Pvclust: Hierarchical clustering with P-Values via multiscale bootstrap resampling. $\mathrm{R}$ package version 2.0-0.

Talwar, P.K. \& Jhingram, A.G. (1991). Inland fisheries of India and adjacent countries. Volume I and II. New Delhi, India, Oxford and IBH Publishing Co..

Tejerina-Garro, F.L., Fortin, R. \& Rodriguez, M.A. (1998). Fish community structure in relation to environmental variation in floodplain lakes of the Araguaia River, Amazon Basin. Environmental Biology of Fisheries, 5: 399-410.

ter Braak, C. \& Prentice I.C. (1988). A theory of gradient analysis. Advance Ecology Research, 18: 271-317.

Trivedy, R.K. \& Goel, P.K. (1989). Chemical and biological methods for water pollution studies. Karad, India, Environmental publication.

Winemiller, K. O., Tarim, S., Shormann, D. \& Cotner, J.B. (2000). Fish assemblage structure in relation to environmental variation among Brazos River oxbow lakes. Transactions of the American Fisheries Society, 129: 451- 468.

Ye, S. (2007). Studies on fish communities and trophic network model of shallow lakes along the middle reach of Yangtze River. ( $\mathrm{PhD}$ thesis), Institute of Hydrobiology, Chinese Academy of Sciences, Wuhan.

Zhao, S., Fang, J., Peng, C., Tang, Z. \& Piao, S. (2006). Patterns of fish species richness in China's lakes. Global Ecology and Biogeography, 15: 386-394. 